\title{
The chain of lifelong learning: linking private and public; singular and societal
}

\author{
Stephen Roche ${ }^{1}$
}

Published online: 19 July 2015

(C) Springer Science+Business Media Dordrecht and UNESCO Institute for Lifelong Learning 2015

We concluded the last issue of this journal with a paper by discussing how lifelong/ lifewide learning is being operationalised in adult education in New Zealand. The author identified significant tension between the market-oriented priorities of the state and the life development needs of adult learners (Zepke 2015). We begin this issue on a similar note, with an analysis by Kapil Dev Regmi of a broad range of national and international policy documents on lifelong learning. The author identifies two principal models that underlie most of these policies; the "human capital model" and the "humanistic model". The former aims to increase productive capacity by encouraging competition, privatisation and human capital formation so as to enhance economic growth. The latter aims to strengthen democracy and social welfare by fostering citizenship education, building social capital and expanding capability. The advantage of boiling things down to these two models is that we can more easily identify the main ideological seams that run through the lifelong learning discourse.

In this paper, entitled "Lifelong learning: Foundational models, underlying assumptions and critiques", Regmi adopts a dispassionate and even-handed approach, advocating for neither of the two models. Rather, he succeeds in revealing the assumptions and rationales that motivate the two strands, presenting the arguments for and against each model. One of the main critiques of the human capital model is that it is founded on competitiveness, which, while enhancing efficiency in some circumstances, produces losers as well as winners. Its critics also charge that it fosters acquiescence with the existing order, rather than active critical citizenship. This model is reflected in policies advanced by the Organisation for Economic Cooperation and Development (OECD), the World Bank and, to a lesser extent, the European Union, and has had most influence in the Anglophone

Stephen Roche

s.roche@unesco.org

1 UNESCO Institute for Lifelong Learning, Hamburg, Germany 
countries of the global North, where lifelong learning is often understood as the policy foundation for a knowledge economy. The humanistic model has been largely championed by UNESCO, some international agencies such as the Southern African Development Community, and by many NGOs. It is probably best exemplified by the Nordic system of lifelong learning, which prioritises citizenship education, high rates of participation, and the building of "social capital". The success of these countries in international comparative assessment studies presents a potent argument to the human capitalists but does little to refute the charge that this model promotes educational worldviews associated with the global North.

In recent years, the Education for All movement has broadened its focus from educational provision to educational quality. Many recent and current interventions focus on literacy, which is the core skill required for further academic success. Despite this focus on the quality of literacy instruction in developing countries, little rigorous research has been conducted on critical issues of assessment. In the second article in this issue, entitled "Assessing reading fluency in Kenya: Oral or silent assessment?", Benjamin Piper and Stephanie Simmons Zuilkowski use data from the Primary Math and Reading Initiative (PRIMR) study in Kenya, ${ }^{1}$ to address a key assessment issue - should literacy assessments in Kenya be administered orally or silently? The authors compared second-grade students' scores on oral and silent reading tasks of RTI International's Early Grade Reading Assessment (EGRA) in Kiswahili and English, and found no statistically significant differences in either language. They did, however, find oral reading rates to be more strongly related to reading comprehension scores. Oral assessment has another benefit for programme evaluators - it allows for the collection of data on student errors, and thus the calculation of words read correctly per minute, as opposed to simply words read per minute. The authors therefore recommend that, in Kenya and similar contexts, student reading fluency be assessed via oral rather than silent assessment.

The education system in Qatar comprises of private schools, which receive money through student fees, and public schools, which are fully governmentfunded. In the mid-2000s, Qatar began a transition towards an independent school model with the aim of eventually converting all public schools into governmentsupported independent schools. The idea was to give public schools more autonomy in terms of hiring decisions, adoption of curriculum and textbooks, and budget spending, enabling them to emulate some of the private schools' strategies for turning out successful students. In a study entitled "The private-public literacy divide amid educational reform in Qatar: What does PISA tell us?" author Jehanzeb $R$. Cheema examines evidence from the 2006-2012 administrations of the Program for International Student Assessment (PISA) in Qatar to evaluate whether or not recent educational reform efforts in this country have succeeded in bridging the literacy divide between private and public schools. The results, presented in a number of detailed tables and discussed in the last part of the article, indicate that there is a significant difference in key literacy skills between the two types of

\footnotetext{
1 PRIMR was led by the NGO RTI International and funded by the United States Agency for International Development (USAID) and the United Kingdom's Department for International Development (DFID).
} 
schools. Private schools were found to outperform their public counterparts in areas such as mathematics, reading and science, both before and after controlling for important student-level differences, and this gap evidently persisted from 2006 to 2012.

The latter three articles in this issue focus on learning needs of and provision to three marginalised and highly vulnerable groups: informal workers, migrants and refugees. The informal sector dominates India's economic life, accounting for around 60 per cent of the country's economic output and employing more than 90 per cent of all workers (ILO 2002; World Bank 2008). It is therefore important, in any discussion of vocational training and skills development in India, to consider the needs and circumstances of informal workers, defined by the Government of India as "those who do not have employment security, work security and social security" (Government of India 2007, p. i). Using data collected in a survey of 49 street food vendors in the Indian cities of New Delhi and Coimbatore, the authors of the fourth article in this issue - Matthias Pilz, Gengaiah Uma and Rengan Venkatram - demonstrate that informal learning represents a particularly significant form of vocational education and training. Their paper is entitled "Skills development in the informal sector in India: The case of street food vendors".

As most Indian street vendors do not acquire skills in formal vocational education and training (VET) settings, opportunities for learning on the job in family businesses or in informal employment are especially important. The authors' findings show that street food vendors acquire a wide range of specialist knowledge, skills and expertise required to conduct their business profitably. These include preparing and selling food but also extend to other areas such as price setting and marketing. All of the street food vendors interviewed identified strongly with their occupation and expressed pride in it. Around half voiced a wish for further training. In this context, the authors suggest promoting non-formal learning settings geared explicitly to street food vendors' difficult working conditions. In line with a few other international innovative schemes, they term this a "non-formal apprenticeship" approach.

Another group that has experienced marginalisation in education are the millions of internal migrants in China. The wave of internal migration that followed China's economic reforms in the early 1990s has not yet subsided. Between 1990 and 2012, China's largest city, Shanghai, experienced an inflow rate of migrants averaging 10 per cent of its total population (Shanghai Municipal Statistics Bureau 2014). In her article entitled "The re-socialisation of migrants in a local community in Shanghai, China", Bo Chang looks at how the Zhabei District of Shanghai provided programmes and services to migrants from other parts of China, particularly lowerincome migrants with residence cards but without stable jobs, and helped them resocialise in their new locality. By examining the component parts of re-socialisation (integration, assimilation and culturalisation), she analyses how the learning programmes and services provided in Zhabei played a role in migrants' adaptation to their new environment.

The author conducted interviews with migrants of both rural and urban origin, and complemented her respondents' statements with formal and informal background research. Her findings indicate that participation in educational activity is only one aspect of migrants' re-socialisation. She demonstrates how educational activities 
merge into a larger community context and are mingled simultaneously with other activities which relate to employment, healthcare, setting up a business, etc. She argues that educational activity loses its backbone if the initial entry-level support given to migrants is not followed up with advanced development activities, such as providing migrants with lifelong learning opportunities tailored to their aptitudes and needs, motivating them to engage in learning which can serve as a pathway towards their career goals, and helping them improve their life circumstances. Thus, educational activity is just one link in the chain of lifelong learning.

We conclude this issue with a study focusing on perhaps the most vulnerable and marginalised group of all: refugees. According to the United Nations High Commission for Refugees (UNHCR), the world is in the midst of its largest human displacement crisis since the Second World War. By the end of 2014, 59.5 million people worldwide were in a condition of forcible displacement as a result of persecution, conflict, violence or human rights violations. Of these, 19.5 million are refugees (persons displaced outside of their national boundaries) (UNHCR 2015). Refugees experience limited access to adequate education at all levels, but opportunities for higher education are especially lacking. Yet, evidence suggests that education plays an important protective role in helping refugee individuals and communities cope during protracted waiting periods, and UNHCR recently recognised tertiary education as a basic human right. In their research note entitled "Higher education for refugees: Lessons from a 4-year pilot project" authors Thomas M. Crea and Mary McFarland present findings from the evaluation of a pilot programme, Jesuit Commons: Higher Education at the Margins (JC:HEM), which initially provided higher education to refugees in Kakuma Camp, Kenya and Dzaleka Camp, Malawi, and to urban refugees in Amman, Jordan.

The authors review the progress made towards the pilot objectives, and present student feedback on the benefits and challenges of higher education for refugees and other marginalised groups. The refugees interviewed in this study expressed feelings of empowerment related to an expanded worldview and to a specific set of skills obtained through participation in the programme. Interviewees also noted a number of limitations specific to the context of their living conditions. Particularly in refugee camps, students expressed concerns about what would happen after their having completed their course. The general outcome of the pilot phase, which ended in 2014, was that the programme addresses a critical need and that it should be continued, albeit with key modifications in its design and delivery. Key areas for future growth of the programme include curriculum transformation, integrated service delivery and university engagement.

\section{References}

Government of India (2007). Report on conditions of work and promotion of livelihoods in the unorganised sector. New Delhi: National Commission for Enterprises in the Unorganised Sector.

ILO (International Labour Organization). (2002). Women and men in the informal economy: A statistical picture. Geneva: ILO. 
Shanghai Municipal Statistics Bureau (2014). Table 2.4 Migration in main years (1990-2012). http:// www.stats-sh.gov.cn/tjnj/nje13.htm?d1=2013tjnje/E0204.htm. Accessed 24 June 2015.

UNHCR (United Nations High Commission for Refugees). (2015). Global trends: Forced displacement in 2014. Geneva: UNHCR.

World Bank (2008). Skill development in India: The vocational education and training system. Report No. 22. Washington: World Bank.

Zepke, N. (2015). Purposes, pedagogies and practices in lifewide adult education in New Zealand: A preview. International Review of Education. 61(1), 99-114. 